15. Paul L. Chretien, Sandrine Laurent, Isabelle Bornard, Claire Troulet, Mohamed El Maâtaoui, et al.. Unraveling the infection process of garlic by Fusarium proliferatum, the causal agent of root rot. Phytopathologia Mediterranea, Firenze University Press, 2020. № 59. P. 285-293.

16. Weir T.L., Park S.W., Vivanco J.M. Biochemical and physiological mechanisms mediated by allelochemicals. Curr. Opin. Plant Biol. 2004. V. 7. P. 472-479.

DOI https://doi.org/10.30525/978-9934-26-047-6-12

\title{
TYPOLOGICAL DIVERSITY OF FORESTS IN THE CATCHMENT AREAS OF THE RIVERS OF THE LEFT-BANK FOREST-STEPPE
}

\author{
Bondar O. B. \\ Candidate of Agricultural Sciences (Ph. D.), \\ Senior Lecturer at the Department of Biology, \\ Ecology and Methods of Teaching \\ Taras Shevchenko Regional Humanitarian-Pedagogical Academy \\ of Kremenets \\ Kremenets, Ternopil region, Ukraine \\ Tkach L. I. \\ Candidate of Agricultural Sciences (Ph. D.), \\ Associate Professor at the Engineering Ecology of Cities \\ O. M. Beketov National University of Urban Economy in Kharkiv \\ Kharkiv, Ukraine \\ Halahan O. K. \\ Candidate of Biological Sciences (Ph. D.), \\ Associate Professor at the Biology, Ecology and Methods of Teaching \\ Taras Shevchenko Regional Humanitarian-Pedagogical Academy \\ of Kremenets \\ Kremenets, Ternopil region, Ukraine
}

Farm management in watershed year should be primarily aimed at strengthening of water protection and eco-stabilizing functions. Solution of these problems regarding preserving and enhancing of these functions is possible, taking into account typological characteristics of forests. These 
features are unique and specific for different watersheds, even within a forest vegetation zone, as they determined by the characteristics of the river geomorphology, soils and microclimate, which stipulate the typological diversity of forests $[4,5]$.

The aim of the work is to determine the distribution of the two most common types of forests in the catchment areas of the tributaries of the Sula, the Psel, the Vorskla and the Severskyi Donets.

The program MapInfo Professional 12.5 and a vector map of Ukraine were used to highlight the boundaries of the catchment areas of the tributaries of the Sula, the Psel, the Vorskla and the Severskyi Donets. An electronic database of the production Association «Ukrglesproject» was used for the analysis of the forest fund of forestry enterprises in the catchment areas of the tributaries of the Sula, the Psel, the Vorskla and the Severskyi Donets. The analysis of the experimental data was carried out with using some computer applications and some geo-information technologies. The methodological provisions of the Ukrainian forest typological school are used for the typological analysis of forests [2]

We analyzed the distribution of dominant types of forest of the maplelinden forest and the fresh oak-pine forest on 75 tributaries of the Psel, the Vorskla and the Severskyi Donets and the distribution of fresh hornbeam and maple-linden forest on 20 tributaries of the Sula. The distribution of the number of forest types in the catchment areas of the tributaries of the Sula, the Psel, the Vorskla and the Severskyi Donets was carried out according to the banks (left and right), flows (upper, middle and lower) and trophotope (forests, subors, sudubravas and oakwoods). B. F. Ostapenko and V. P. Tkach (made a comparison between the types of forests mentioned before. So, it was established that 28 types of forest were identified by forest management and these types were not described by scientists.

The typological structure in the catchment areas of the rivers of the LeftBank Forest-Steppe is quite diverse and is generally represented by 62 types of forests. Within some separate catchment areas, the number of forest types are represented. There are 49 types in each catchment area of the Sula [1] and the Psel rivers [8], 46 are in the catchment area of the Vorskla river [9] and 32 are in the catchment area of the Severskyi Donets river [10]. In addition, a large variety of forest types requires the implantation of differentiated management systems, taking into account the natural features of the catchment areas of rivers. Fresh maple-linden forest is the predominant and zonal type of forest $\left(\mathrm{D}_{2}-\mathrm{mlO}\right)$, which generally covers an area of more than 230 thousand square hectares or $46 \%$ of the total area covered with forest vegetation. Within the catchment areas of the Psel, the 
Vorskla and the Sevetskiy Donets rivers, a part of the $\mathrm{D}_{2}$-mlO consists about half of the area covered with forest vegetation $(45 \%, 47 \%$ and $54 \%$ respectively or 61.7, 55.8 and 96.2 thousand hectares.) As a result of the analysis, 28 types of forests were indicated and they were not previously studied, but they were identified by forest management. Therefore, during keeping the next record of the forest fund it is necessary to clarify and coordinate the names of the relevant forest types. In the future, scientific research on the study of forests and forest types should be extended and improved taking into account the characteristics of the catchment areas of rivers.

\section{References:}

1. Бондар О. Б. Типологічна структура лісів водозборів річки Сула. Вісник ХНАУ ім. В. В. Докучаєва. Харків: ХНАУ, 2016. № 2. С. 153-158.

2. Ведмідь М. М., Мєшкова В. Л., Жежкун А. М. Алгоритм для виявлення земель малоцінних молодняків у дібровах за матеріалами лісовпорядкування. Лісівництво і агролісомеліорація. Харків: 2006. Вип. 110. С. 54-59.

3. Воробьев Д. В. Методика лесотипологических исследований. Киев : Урожай, 1967. 330 с.

4. Мигунова Е. С. Лесная типология в Украине типология. Харьков : Планета-Принт. 2017. 50 с.

5. Назаренко В. В., Пастернак В. П. Закономірності формування типів лісу Лісостепу Харківщини: монографія. Харків: ХНАУ, 2016. $190 \mathrm{c}$.

6. Ткач Л. І., Бондар О. Б. Типологічне різноманіття лісів водозборів річки Псел. Науковий вісник НЛТУ України. 2016. Вип. 26.5. С. 153-161.

7. Ткач Л. І., Бондар О. Б., Солодовник В. А. Типологічна структура та біорізноманіття лісів малих водозборів річки Ворскла. Науковий вісник НУБІП України. Київ: ВЦ НУБІП України, 2016. Вип. 238. Ч. 1. С. $56-65$.

8. Ткач Л. І., Бондар О. Б. Типологічна структура лісів водозборів річки Сіверський Донець. Лісівництво і агролісомеліорація. 2015. Вип. 126. С. 106-113. 